\title{
HOW ARE EMPLOYMENT AND INCOME INFLUENCE SOCIETY ATTITUDE TO PAY ZAKAT IN SOUTH SUMATERA WITH TAWHIDI PERSPECTIVE
}

\author{
Lily Rahmawati Harahap*), Dwi Eka Novianty, Sri Ermeila \\ University of IBA, Palembang \\ harahaplily@gmail.com
}

\begin{abstract}
The purpose of this article is to share about how important zakat fund which collected and distributed well, according to the rule based on Islam, in order to improve economic. The phenomena in South Sumatera shows unsycnchronized data between Gross Regional Domestic Product and poverty level. South Sumatera province is the top 11 rankings from 34 provinces in Indonesia in terms of GRDP acquisition. But in reality, South Sumatera also the top 18 rankings from 34 provinces in Indonesia in terms of poverty level. This research will discuss the phenomena from society attitude with some factors that might influence, from the tawhidi perspective. Using primary data from 4 regencies and 1 city in South Sumatera and also supported by 2 factors (employment and income), this research describe how are these 2 variables influence society attitude to pay zakat viewed from tawhidi perspective. The result of hypothesis test by using regression model shown that employment variable and income variable influence society attitude to pay zakat simultaneously and partially. With Tawhidi String Relation methode by induced these 2 variables with tetha $(\theta)$ will change the result in the good range.
\end{abstract}

Keywords: zakat, tsr

\section{INTRODUCTION}

The obligation of paying zakat is an important methode to resolve the gap between the haves and the haves-not society. As state in QS Al Mujaadilah verse 13, for Muslims who have not been fulfilled yet sadaqah during talks with Rasulullah, then Allah forgive them if they do salat and pay zakat. Thus the importance of paying zakat which is equated with the importance of prayer. Obaidulllah dan Abd.Latief (2008) explained zakat and sadaqah are main charity instruments in Islamic scheme to alleviate poverty. Sarea (2012) viewed zakat as one of in accordance methode to measure economic growth. The collection of zakat funds can not be separated from society attitude who are concerned of their obligation to pay zakat.

Indonesia as the largest Muslim population country in the world is a great potential in collecting zakat funds. According to Vice Chairman of National Amil Zakat Board, Zainulbahar Noor, Indonesia zakat potential reach 217 trillion rupiah. With this potentiality, zakat fund will be able to help government in order to alleviate poverty. 
Unfortunately, the collecting of zakat funds only about 3 trillion rupiah or about 1.2 percent (https://m.tempo.co).: 2016). This research is done in South Sumatera, represent by 4 regents and 1 city to find out the relevance between 2 explanatory variables influence society attitude in paying zakat viewed from tawhidi perspective. Society here means the person who has an obligation to pay zakat.

South Sumatera is one of province locates in the shouthern part of Sumatera island. It rich in natural resources such as petroleum, natural gas and coal. Besides, the province has many attractive tourist destination to visit, and indirectly influence the culture of the society. With $91.592,43 \mathrm{~km}^{2}$ area, South Sumatera is the largest province in Sumatera island. Its economic performance continues to strengthen each year. Economic growth is supported by the magnitude of regional gross domestic product continues to increase. The datas explaine South Sumatera is the highest ratings to 11 of 34 provinces in Indonesia in regional gross domestic product acquisition. But on the contrary, it is also the poorest province ranked 18 out of 34 provinces in Indonesia. Simply it indicates that the richness have not been distributed evenly and have not been able to improve the wellbeing of society. If seen from the datas, it should be positively correlate with the ability of society to be able to share sustenance, especially from zakat.

From these explanations can be stated that local government is not fully able to handle these poverty problems. Assuming that if large regional income will automatically increase the welfare of the society turned out not currently fully valid. Zakat fund is as an alternative and also as a main supporter to alleviate poverty. Society's role as a muzakki and mustahiq are very expected to assist the implementation of the collection and distribution of zakat on purpose in order to alleviate poverty.

\section{LITERATURE REVIEW}

\subsection{Definition and The Basic Concept Of Zakat.}

Zakat word comes from zaka, in terminology has many meaning, that is sacred, grow, blessing, praise and develop (Mardhani, 2013). In addition, the charity could also mean a certain amount of a certain assets assigned to a particular person (Sholihin, 2010). While in Government On Law No. 23 Year 2011 on the Management of Zakat, which meant Zakat is an asset that must be issued by a Muslim or a business entity to be given to those who deserve it in accordance with Islamic syaria (www.sumsel.kemenag.go.id).

The most accurate way to overcome the gap between the haves and the haves-not is the obligation to pay zakat to those who are already qualified. Terms someone obliged to give zakat are: 1) Moslem, 2) Independence, 3) Baligh, 4) The conditon of the asset, the asset develops, 5) The condition of the assets until the nisab. By paying zakat, then it will manifest unity in Islam portrayed on the lessons learned, namely: 1) maintain and protect the asset from the sight of others, 2) to help poor people and those in need, 3) purify oneself from miser, accustom moslems for giving and generous, so that not only gives limited to only zakat (Az-Zuhaili, 2011). It shows the basic concept of zakat, namely that with paying zakat regularly, then all good things will be back, either to the person who paying zakat (muzakki) or also to the person who receive zakat (mustahiq).

\subsection{Relationship Between The} Variables and Society Attitude.

Every human being can not be separated from the things that affect 
their lives. 2 variables of many variables that influence society attitude are employment and income. This paper reviews the relationship between these 2 variables on the society attitude to pay zakat.

\subsubsection{Employment}

Islam is a guidance and teachings for Muslim way of life in this earth. These teachings encouraged the people to work hard and spirited, avoid laziness and always do the charity. QS At Taubah verse 103 explain about the importance of paying zakat to purify and cleanse themselves. Thus, everyone will be trying to replenish themselves and sharing with others, the way to work and try as much as possible as well. In Islam, working for living is one way of jihad. Islam motivate every believer to avoid attitude that show weakness.

\subsubsection{Income}

According to PSAK No.23 paragraph 6 , the meaning of income is the gross inflow of economy benefits arising from the company normal activity during a period when those inflows result in increase in equity that do not come from the contribution of capital invesment. To obtain income, every human must work hard and seriously. QS Al Furgaan verse 47 explains about Allah's gift to human about the time difference to look for sustenance and time to rest. Thus the attention of Allah to His creatures. Although human try to earn as much as possible, he is recommended to do rest. Yogatama (2010) in his research concluded that income level factor showed positive and significant effect on the probability of adherence to fulfill the obligation paying zakat. Rouf (2011) explain that income is one factors that influence sinificantly society interest in giving zakat at Semarang Zakat House. The respondents agree that the more income the stronger the desire in giving zakat.

\subsection{Tawhidi String Relation (TSR) Concept}

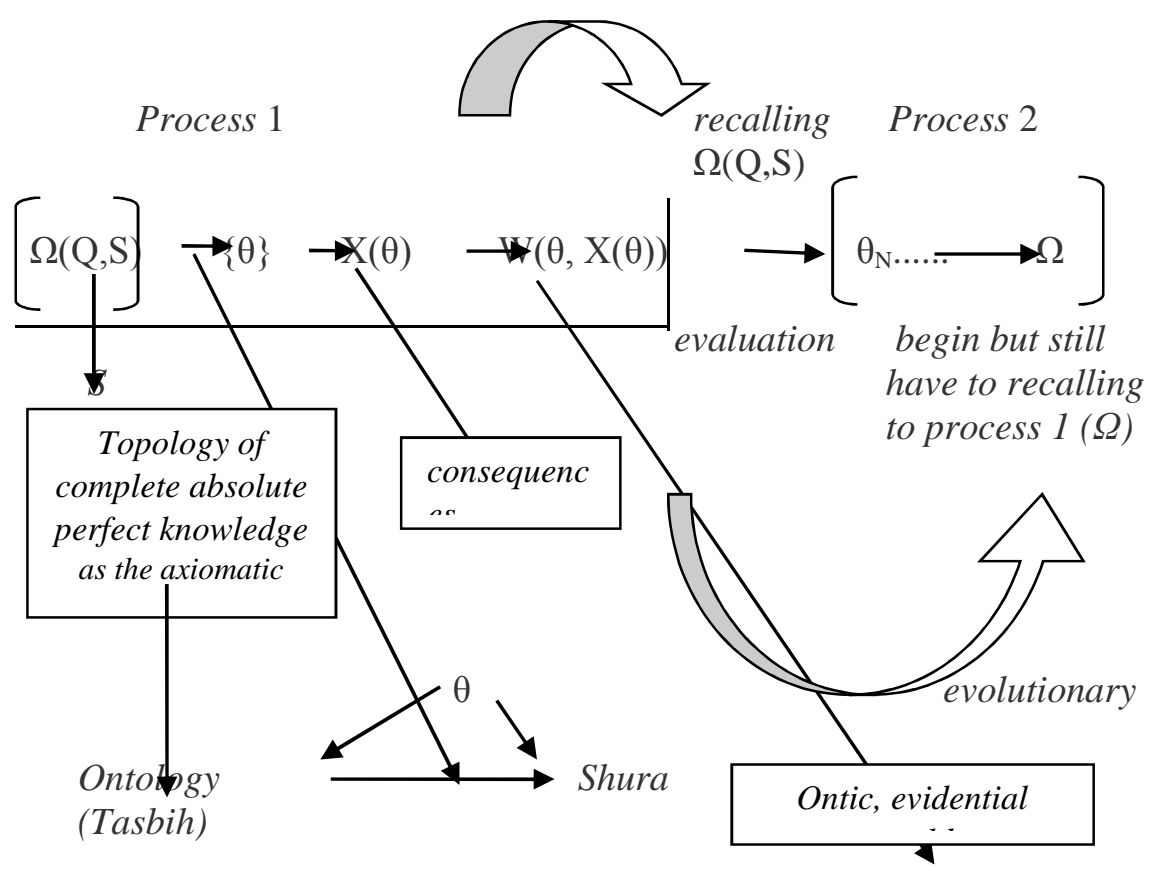

Figure 1.

The Formal Concept of Unity Of Knowledge (Tawhidi): The IIE or Shuratic Process 
For the Moslems, tawhid word is familiar. Tawhid means the oneness of Allah. This oneness of Allah described in $\mathrm{Al}$ Quran and Hadith as the foundation of all the roots of science. Essentially, the understanding of tawhid covers all matters relating to oneness of Allah, with varied opinions of the unitary system of knowledge, gained by following Rasulullah (sunnah) guidance in all activities in the entire world system (Choudhury, 2011). The source of knowledge derives from Al Quran is gives as omega $(\Omega)$. As a guidance for mankind, the implementation is done for what Rasulullah has done, which called Sunnah (S). In other words, TSR concept derived from $\mathrm{Al}$ Quran and Sunnah $(\Omega, S)$, describes the unity of knowledge $(\theta)$, ongoing activities, learning process, social interaction system, integration, cooperation, sincerity for complementary and subsistence (Choudhury, 2013).

TSR concept describes the delivery beginning process of knowledge until the implementation for human kindness. It is done by shuratic process with partisipation and complementary (pairing) methode. In this shuratic process, there is an interaction (I) between all parties in it. From this interaction will increase an integration (I), that shows a consensus. The integration will evolute to the next process to evaluation previous process and move forward to the next process. This IIE process will produce a sosial wellbeing and the notation is $\mathrm{W}\{\theta, \mathrm{X}(\theta)\}$ (Choudhury, 2013).

\section{RESEARCH METHOD}

This research is done to society from 4 regencies (OKU Timur, Muara Enim, BanyuAsin, Musi Bayu Asin) and 1 city (Palembang) in South Sumatera province. 592 respondents tested the validity with loading factor is 0.30 (Hair et.al., 2016) and also reliability test using Alfa Cronbach's (if alpha value > 0.60 , both the questions and statements are reliable). It used a linear regression test to find the correllation between the variables.

\subsection{Conceptual Framework}

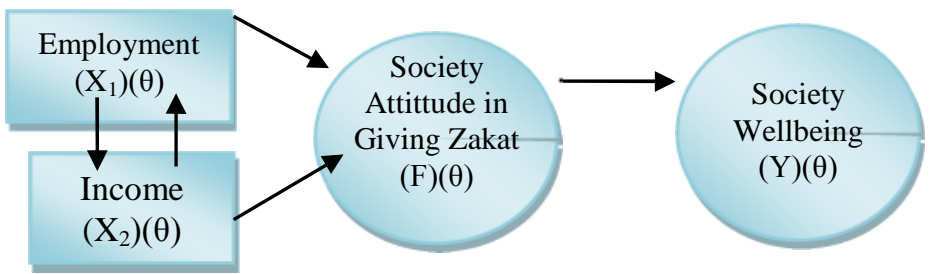

Figure 2

Conceptual Framework

Source: Processed (2018).

Figure 3.1 explains the relationship model between variables that influence society attitude to pay zakat and society wellbeing. According to the model, it will calculated the variables value which influence society attitude to pay zakat. As it has been known, TSR concept is a pervasive complementary, not a subtitution. In other words, those $\mathrm{X}$ dan $\mathrm{Y}$ variables complement each other. Every variable will embeed by tetha, wherein each variable interconnected to one another to form circular causation. In mathematics, this concept will create a model: 
SA

$$
=\mathrm{f}(\mathrm{EMP}, \mathrm{INC})(\theta)
$$$$
=\mathrm{f}\{\operatorname{EMP}(\theta), \operatorname{INC}(\theta)\}
$$

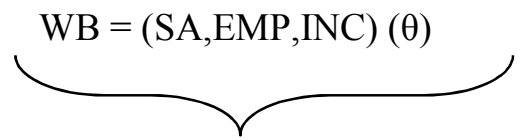

Evaluation is done by estimation and simulation to form a circular causation model as follows:

$\mathrm{SA}=\mathrm{f}_{\mathrm{SA}}(\mathrm{EMP}, \mathrm{INC})(\theta)$

The value in each variable will influence another variable. The change of percentage in one variable will change another variable as they are. The resulting value on the relationship of each variable can be expected in positive value, but will possibly show a negative value. If the result is negative value, simulation will be done to change
$\mathrm{INC}=\mathrm{f}_{\mathrm{INC}}(\mathrm{SA}, \mathrm{EMP})(\theta)$

$(\theta) \quad=$ WB $\Sigma($ SA, EMP, INC) $(\theta)$

The linear equation $(\mathrm{Y}=\alpha+\beta \mathrm{X})$ from the model is:

$$
\begin{gathered}
\mathrm{SA}=\alpha_{1.0}+\beta_{1.1} \mathrm{EMP}+\beta_{1.2} \mathrm{INC}+\beta_{1.3} \theta \\
\mathrm{EMP}=\alpha_{2.0}+\beta_{2.1} \mathrm{SA}++\beta_{2.2} \mathrm{INC}+\beta_{2.3} \theta \\
\mathrm{INC}=\alpha_{3.0}+\beta_{3.1} \mathrm{SA}+\beta_{3.2} \mathrm{EMp}+\beta_{3.3} \theta \\
(\theta)=\alpha_{4.0}+\beta_{4.1} \mathrm{SA}+\beta 4_{5.2} \mathrm{EMp}+ \\
\beta_{4.3} \mathrm{INC}+\beta_{4.4} \theta
\end{gathered}
$$

negative value into positive. The value will choosen by observation of the things pertaining to the variable and also do the shuratic process to the competent persons. The positive value describes a good society attitude to pay zakat, which in turn have a positive impact on improving society wellbeing.

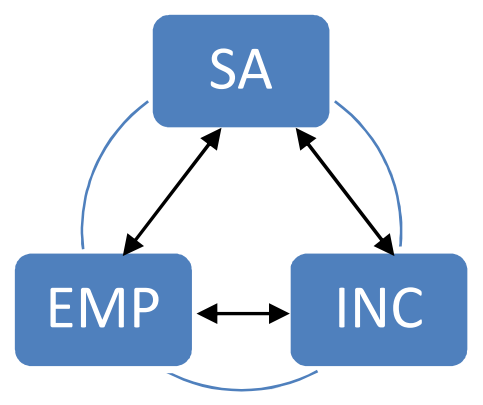

Figure 3

Intercausality between SA, EMP and INC

Figure 3 shows intercausality between 2 explanatory variables form society attitude to obtain a wellbeing. Each variables are complementary and not a substitution for other variables. There are a pairing. This intercausality is a result from interaction process (from a small group). It begins from relationship between person to person from a relation activities with employment and income. In this activities, there is a conformity and nonconformity. There is an evaluation to form an integration, that is the relation between group from these three variables. Integration process is done by repeated evaluation to find conformity inter and intra group. Evaluation is done by learning previuos phase. If there is a conformity, then it will be an evolution, that is the transfer to the second phase of the re-starting of the interaction, then integration and evolution process. This IIE process will continue until the end of the world, make a circular causation to obtain a wellbeing. 


\section{RESULT AND DISCUSSION}

According to the validity and reliablity test can be explained that every statement item given to the respondent is in relation to employment and income are valid and reliable. The value of the test shows $r_{\text {table }}<r_{\text {count }}$, also Cronbach's Alpha > Cronbach's Alpha Value.

\section{Hyphotesis Test.}

Table 1

Simultaneously Hyphotesis Test

\begin{tabular}{|l|r|r|r|r|l|}
\hline \multicolumn{1}{|c|}{ Model } & Sum of Squares & \multicolumn{1}{c|}{ df } & Mean Square & F & Sig. \\
\hline Regression & 84.796 & 2 & 42.398 & 663.634 & $.000^{\mathrm{b}}$ \\
\hline Residual & 37.630 & 589 & .064 & & \\
\hline Total & 122.426 & 591 & & & \\
\hline
\end{tabular}

a. Dependent Variable: Attitude (Y)

b. Predictors: (constant), Income (X2), Employment (X1)

Table 1 shows $F_{\text {value }}(663,634) \geq F_{\text {tabel }}$ (2.312). $\mathrm{H}_{\mathrm{a} 1}$ is accepted. It means employment variable and income variable influence society attitude to pay zakat in 4 regents and 1 city at South Sumatera simultaneously.

Table 2

Partially Hyphotesis Test

\begin{tabular}{|l|r|r|}
\hline \multicolumn{1}{|c|}{ Model } & T & Sig. \\
\hline (Constant) & 9.066 & .000 \\
\hline Employment(X1) & 9.358 & .000 \\
\hline Income(X2) & 27.957 & .000 \\
\hline
\end{tabular}

a.Dependent Variable :Attitude (Y)

Table 2 shows employment variable has t-value $(9.358)>\mathrm{t}$ table (1.647) and income variable has $\mathrm{t}$-value $(27.957)>\mathrm{t}$ table (1.647). $\mathrm{H}_{\mathrm{a}}$ accepted. It means employment variable and income variable influence society attitude to pay zakat in 4 regents and 1 city at South Sumatera partially

Table 3

The Influence of Employment and Income Variables to Society Attitude

\begin{tabular}{|l|c|r|r|r|}
\hline Model & $\mathrm{R}$ & R Square & Adjusted R Square & Std. Error of the Estimate \\
\hline 1 & $.832^{\mathrm{a}}$ & .693 & .692 & .253 \\
\hline
\end{tabular}

a. Predictors: (Constant), Employment (X1), Income (X2)

b. Dependent Variable: Attitude (Y)

Table 3shows $\mathrm{R}$ square $\left(\mathrm{R}^{2}\right)=$ 0.693. It means employmement variable and income variable influence society attitude about $69.30 \%$ and about $30.70 \%$ it influenced by other variables.
Employment variable influences society attitude about $17.30 \%$ and income variable influences society attitude about $52 \%$. 


\section{TSR Analysis}

From the results of the questionnaire using a likert scale of 5 points obtained average rate society attitude to pay zakat in South Sumatera influenced by 2 variables. Table 4.4 to
4.6. explain the coefficient regression value between variables according to the tsr methode, which every variable has opportunity become explanatory variables as well as explained variables.

Table 4

Linear Regression Income Variable

Coefficients

\begin{tabular}{|l|l|l|r|}
\hline \multirow{2}{*}{ Model } & \multicolumn{2}{|c|}{ Unstandardized Coeff. } & Standardized Coeff. \\
\cline { 2 - 4 } & B & Std Error & Beta \\
\hline (Constant) & 1.594 & .172 & -.019 \\
\hline income & -.019 & .059 & .549 \\
\hline social_attitude & .660 & .070 & \\
\hline
\end{tabular}

Dependent Variable : Employment

Source : Processed Data (2018)

From Table 4 the first linear equation is:

Empl $=\alpha_{1.0}+\beta_{1.2}$ Inc $+\beta_{1.3} S A$

$\mathrm{Empl}=1.594-0.019 \mathrm{Inc} \theta_{2}+0,660 \mathrm{SA}_{3}$

Table 5

Linear Regression Society Attitude Variable

Coefficients

\begin{tabular}{|l|c|r|r|}
\hline \multirow{2}{*}{ Model } & \multicolumn{2}{|c|}{ Unstandardized Coeff. } & Standardized Coeff. \\
\cline { 2 - 4 } & B & Std Error & \multicolumn{2}{c|}{ Beta } \\
\hline (Constant) & .164 & .129 & .809 \\
\hline social_attitude & .968 & .035 & -.009 \\
\hline employment & -.009 & .029 & \\
\hline
\end{tabular}

Dependent Variable : Income

Source : Processed Data (2018)

From Table 5. the second linear equation is:

Inc $=\alpha_{1.0}+\beta_{1.1}$ Emp $+\beta_{1.3}$ SA

Inc $=0.164-0.009 \mathrm{Emp} \theta_{1}+0,968 \mathrm{SA} \theta_{3}$

Table 6

Linear Regression Employment Variable

Coefficients

\begin{tabular}{|l|c|c|c|}
\hline \multirow{2}{*}{ Model } & \multicolumn{2}{|c|}{ Unstandardized Coeff. } & \multicolumn{2}{c|}{ Standardized Coeff. } \\
\cline { 2 - 4 } & B & Std Error & \multicolumn{2}{c|}{ Beta } \\
\hline (Constant) & .853 & .094 & .236 \\
\hline employment & .196 & .021 & .705 \\
\hline income & .589 & .021 & \\
\hline
\end{tabular}

Dependent Variable : Social Attitude

Source : Processed Data (2018)

From Table 6 the third linear equation is:

$\mathrm{SA}=\alpha_{1.0}+\beta_{11} \mathrm{Emp}+\beta_{1.2}$ Inc

$\mathrm{SA}=0.853+0.196 \mathrm{Emp}_{1}+0,589 \operatorname{Inc} \theta_{2}$ 
Table 7

Regression Running Data Result

\begin{tabular}{|l|r|r|l|}
\hline \multicolumn{1}{|c|}{ Item/Y } & \multicolumn{1}{c|}{ EMP } & \multicolumn{1}{c|}{ INC } & \multicolumn{1}{c|}{ SA } \\
\hline Konstan & 1.594 & 0.164 & 0.853 \\
\hline $\mathrm{a}_{2}=$ EMP & & -0.009 & 0.916 \\
\hline$\theta_{2}=\mathrm{X} 2$ & & 4.062 & 4.062 \\
\hline $\mathrm{a}_{3}=\mathrm{INC}$ & $-0,019$ & & 0,589 \\
\hline$\theta_{3}=\mathrm{X} 3$ & 4,193 & & 4,193 \\
\hline $\mathrm{a}_{8}=\mathrm{SA}$ & $-0,660$ & 0,968 & \\
\hline$\theta_{8}=\mathrm{X} 4$ & 4,126 & 4,126 & \\
\hline
\end{tabular}

Source: Processed Data (2018).

Table 7 explains how much every coefficient value of explanatory variables

(in the area) generates a value for explained variables (outside the area). For example, value of -0.019 explains that income variable generates employment as the value shown. While value -0.009 explains that employment variable generates income variable as the value shown. This inter and intra variables linkages will generate a circular causation.

\section{Equation Model}

These equation models are made to find tetha hat $\left(\theta^{\wedge}\right)$ result, ie by embedding tetha $(\theta)$ on each variables coefficient regression value. Tetha $(\theta)$ value is an actual data value, while tetha hat $\left(\theta^{\wedge}\right)$ value is an estimation data value.

Equation 1: employment variable as an explained variable.

$$
\begin{aligned}
\theta_{1} \wedge=X_{1}= & 1.594-0.019 \theta_{2}+0.660 \theta_{3} \\
= & 1.594-0.019(4,193)+0.660 \\
& (4,126)=4.101 .
\end{aligned}
$$

From equation 1 obtained tetha hat $\left(\theta^{\wedge}\right)$ value or estimation data value 4.101, while actual data value 4.062 . There is an decrease amount 0.039 .
Equation 2: income variable as an explained variable.

$\theta_{2} \wedge=X_{2}=0.164-0,009 \theta_{1}+0,968 \theta_{3}$

$$
\begin{aligned}
= & 0.164-0,009(4.062)+ \\
& 0,968(4,126)=4.121 .
\end{aligned}
$$

From equation 2 obtained tetha hat $\left(\theta^{\wedge}\right)$ value or estimation data value 4.121, while actual data value 4,193 . There is an decrease amount 0.072 .

Equation 3: society attitude variable as an explained variable.

$$
\begin{aligned}
\theta_{3^{\wedge}}=\mathrm{X}_{3}=0.853+0,196 \theta_{1}+0.589 \theta_{2} \\
=0.853+0,196(4.062)+0.589
\end{aligned}
$$$$
(4.193)=4.119 \text {. }
$$

From equation 3 obtained tetha hat $\left(\theta^{\wedge}\right)$ value or estimation data value 4.119, while actual data value 4,126 . There is an decrease amount 0.007 .

From these explanations the result that the actual datas show respondents' opinion relation to the variables that form attitude to pay zakat. Using the tawhidi string relation methode with embed tetha in each variables, will generate an assessment toward a good enough up to good. It proves eventhough respondents give a not good assessment, with tawhidi string relation methode can be changed it better. One's faith has a role to make difference. 


\section{CONCLUSION}

From the statistical test can be concluded employment and income variables simultaneously and partially influence society attitude in paying zakat. Partially and also seen from RSquare test, income influence society attitude in paying zakat more significant than employment. If income increase then respondens't attitude to pay zakat

\section{REFERENCES}

Al Qur'an dan Terjemahnya. 1433H. Depag.

Al-Islam.org. (2017). Whati is the Quran. (online-3/4/17). Available www.al-islam.org

Az-Zuhaili,W. (2011). Fiqih Islam Wa Adillatuhu. Puasa, I'tikaf, Zakat, Haji, Umrah. Jilid 3. Jakarta: Gema Insani.

Choudhury, M.A. (2011). Contributions to Economic Analysis: Islamic Economics and Finance An Epistemological Inquiry. United Kingdom: Emerald Group.

Choudhury, M.A. (2013). Handbook of Tawhidi Methodology: Economics, Finance, Society and Science. Jakarta: Trisakti University Press.

Hair, J.,F., Hair, J.F., Black, W.C., Babin, B.J., dan Anderson, R.E. (2016). Multivariate Data Analysis. Seventh Edition. Ebook (online-15/3/16). Available www.pearsonhighered.com

ICRQS. (2017). The True Salat According To Quran. (online3/4/17). Available https://sites.google.com

Islamweb.net, (2017). Who is a Muslim. (online-3/4/17). Available http://www.islamweb.net

Kementerian Agama. (2011). UndangUndang Repulik Indonesia will also increase better than the change of employment.

TSR methode implement that every variables is a pairing and complementary. Though employment variable does not influence society attitude as big as income, but these two variables relate to complement one another.

Nomor 23 Tahun 2011 Tentang Pengelolaan Zakat (online26/2/17). Available www.sumsel.kemenag.go.id

Mardani. (2013). Fiqh Ekonomi Syariah: Fiqh Muamalah. Jakarta: Kencana PrenadaMedia Group.

Masjidku, (2016). Pengertian Mustahik dan Muzakki. (online-3/4/17). Available https://artikel.masjidku.id

Masuk Islam, (2013). Pengertian Dzikir dan Pembahasan Dzikir Lengkap. (online-3/4/17). Available http://www.masukislam.com

Muslim.or.id, (2012). Panduan Zakat. (online-3/4/17). Available https://muslim.or.id

Mutia, A., dan Zahara, A.E. (2009). Analisis Faktor-Faktor Yang Mempengaruhi Kesejahteraan Ekonomi Mustahik Melalui Pemberdayaan Zakat (Studi Kasus Penyaluran Zakat Produktif/Modal Usaha Pada Bazda Kota Jambi). Konstektualita, Vol. 25 No.1, Juli 2009.

Obaidullah, M., dan Abd.Latief, S. (2008). Islamic Finance For Micro And Medium Enterprises. Islamic Research \& Training Institution Islamic Development 
Bank. Center for Islamic Banking, Finance and Management. Universiti Brunei Darussalam.

Portal Infaq. (2006). Definitions of Zakah, Infaq and Shadaqah. (online-3/4/17). Available http://www.portalinfaq.org.uk

Riani, D. (2012). Analisis Faktor-Faktor Yang Mempengaruhi Perilaku Muzakki Dalam Membayar Zakat (Studi Kasus Pada Baznas Kota Yogyakarta) (online26/2/17). Available http://digilib.uin-suka.ac.id

Rouf, M.Abdul. (2011). Analisis FaktorFaktor Yang Mempengaruhi Minat Masyarakat Membayar Zakat Di Rumah Zakat Cabang Semarang. (online-26/2/17). Available http://eprints.walisongo.ac.id
Sarea, A. (2012). Zakat as a Benchmark to Evaluate Economic Growth: An Alternative Approach. International Journal of Business and Social Science, Vol. 3 No. 18.

Sari. (2009). Peran Strategis Zakat Dalam Fungsi Kebijakan Politik Ekonomi Di Indonesia. Tapis, Vol.5, No. 19.

Sholihin, A. I. (2010). Buku Pintar Ekonomi Syariah. Jakarta: PT. Gramedia Pustaka Utama.

Tempo.co. (2016). Ramadan (online-26 /2/17).

Available https://ramadan.tempo.co.

Yogatama, R. A. (2010). VariabelVariabel Yang Mempengaruhi Kepatuhan Menunaikan Zakat : Pendekatan Kontijensi (online17/3/15).

Available 